Artigos 


\section{Deus sem onto-teo-logia: uma questão heideggeriana à luz de Emmanuel Lévinas e Jean-Luc Marion}

\section{God without onto- theo-logy: A Heidegger's question in the light of Emmanuel Levinas and Jean-Luc Marion}

O presente artigo possui como objetivo central caracterizar a ressignificação do conceito de Deus em Lévinas e Marion, levando em consideração o conceito heideggeriano de onto-teo-logia, que simultaneamente pretende caracterizar a essência da metafísica e assinalar o caráter não divino do Deus metafísico considerado causa de si (causa sui), uma vez que, tanto Lévinas quanto Marion, reposicionam a questão de Deus por meio da assunção deste conceito. Neste sentido, Deus é ressignificado por meio da afirmação de sua incondicionalidade, irredutível, portanto, a quaisquer horizontes condicionadores dos fenômenos em geral. Por este motivo, Lévinas e Marion pensam Deus como refratário ao conceito heideggeriano de ser, que posiciona horizontes históricos desveladores da aparição de todo e qualquer ente. Assim, seja no âmbito da virada ética da fenomenologia (Lévinas), que inscreve Deus na significatividade do rosto do outro humano, seja na saturação de todo e qualquer horizonte de sentido (Marion), um Deus não onto-teo-lógico se dá para além do ser.

PALAVRAS ChAVE Onto-teo-logia. Ser. Deus.

This article has as main objective to characterize the redefinition of the concept of God in Levinas and Marion, considering Heidegger's concept of onto-theo-logy, which aims to simultaneously characterize the essence of metaphysics and mark the no divine character of the metaphysical God considered cause of himself (causa sui), since both Levinas as Marion, reposition the question of God through the assumption unconditional, irreducible, so any conditioners horizons of phenomena in general.

Therefore, Levinas and Marion think God as refractory to Heidegger's concept of being, positioning unveilings historical horizons of the appearance of everything. Thus, either within the ethical turn of phenomenology (Levinas), which enlists God in the significance of the face of another human, either in saturation of any horizon of meaning (Marion), a God not ontotheo-logic is given to beyond being. 


\section{Introdução}

O pensamento contemporâneo estrutura-se por meio da crise dos supostos metafísicos que tradicionalmente sustentaram as (meta) narrativas filosóficoteológicas e, por isso mesmo, de formas diversas, esta crise coloca em xeque o poder prescritivo do conceito de Deus. Dito de outro modo: o pensamento contemporâneo perfaz-se por meio da crise da força fundacional do Deus metafísico, suspendendo não somente seu arcabouço semântico, como a "região" ontológica que the fora considerada correlata. O que estamos caracterizando como a crise do Deus metafísico, diretamente dependente da crise das meta-narrativas metafísicas da tradição filosófico-teológica ocidental, aparece caricaturalmente no acontecimento (nietzschiano) da morte de Deus, imperativo histórico que, a um só tempo, conjuga a dissolução do poder vinculador de Deus como princípio metafísico explicativo da semântica do mundo e como valor supremo (absoluto) condicionador dos múltiplos comportamentos humanos. Neste sentido, quando o louco/insensato (der Tolle Mensch) declara que Deus morreu, seu anúncio em forma de denúncia, que visa a caracterizar o deicídio como causa mortis de Deus, assinala justamente a supressão da preservação do Deus suprassensível: "Para onde foi Deus?, gritou ele, 'já lhes direi! Nós o matamos - vocês e eu. Somos todos seus assassinos! Mas como fizemos isso? Como conseguimos beber inteiramente o mar? Quem nos deu a esponja para apagar o horizonte? Que fizemos nós, ao desatar a terra do seu sol?" (NIETZSCHE, 2002, § 125). Não se trata certamente de um grito a mais no coro dos ateísmos ocidentais, que nada mais são que um tipo de teísmo invertido surgido no seio da modernidade, uma vez que, pelo fio condutor da racionalidade, visam a "provar" que o objeto Deus não existe. Como percebeu Heidegger: "O dito 'Deus morreu' significa: o mundo suprasensível está sem força atuante. Ele não irradia nenhuma vida" (HEIDEGGER, 2002, p. 251). Ora, enquanto suprassensível, Deus aparece como "mar", "horizonte" e "sol”, imagens-metáforas que assinalam que Deus sempre fora o princípio omniabarcante estruturador do mundo e da existência humana. O "nós o matamos" dito pelo louco/insensato responsabiliza-nos, todos, pelo deicídio ocorrido no desdobramento da história ocidental. Esta responsabilidade não somente nos envolve na trama da morte de Deus, mas sobretudo nos inscreve nos desdobramentos hermenêuticos deste acontecimento, dentre os quais se destaca o fato de Deus não poder mais ser concebido segundo a noção de causalidade tradicionalmente a ele conectada.

Uma questão, contudo, se nos apresenta como fundamental: ainda que tenhamos que levar adiante os efeitos hermenêuticos da morte de Deus, a ideia 
nietzschiana de que a metafísica se resume no fato de ser uma interpretação binária do real, segundo a qual o mundo é cindido em uma instância meta-empírica e outra sensível (uma funcionando como fundamento ontológico da outra), dá conta da metafísica em sua multiplicidade de configurações históricas e de seus modos de se relacionar com a divindade? Mesmo que Nietzsche tenha assinalado no aforismo 343 de A gaia ciência que a morte de Deus abre novamente o mar1 ${ }^{1}$, isto é, descerra novas interpretações (não metafísicas) do mundo, isto não quer dizer que tais possibilidades por ele percorridas ressignifiquem radicalmente a questão de Deus. O binômio vontade de poder/eterno retorno, que funciona como complexo conceitual caracterizador da dinâmica de realização da imagem nietzschiana da divindade, ou seja, de Dionísio, conforme mostramos alhures (Cf. CABRAL, 2014), condiciona a divindade e delimita seus [de Dionísio] modos de manifestação. Ora, ainda que Nietzsche tenha levado adiante as consequências hermenêuticas da morte de Deus, por exemplo abandonando por completo a conjugação de divindade e causalidade, fato é que sua divindade ainda é subsumida pelo horizonte formado pelo binômio mencionado. Ora, devemos aqui levar em conta que as meta-narrativas metafísicas não somente pensam a divindade como causa suprassensível do sensível (como acertadamente percebeu Nietzsche); ela reconduz a divindade a algum horizonte condicionador de sua manifestação. Isto retira da divindade seu caráter refratário a quaisquer horizontes de condicionamento de seu ser, ou seja, furta da divindade sua absoluta alteridade.

Devemos, no presente estudo, ressignificar o problema de Deus à luz da incondicionalidade de sua (auto) manifestação. Para tanto, devemos lançar mão de outra caracterização da metafísica que a de Nietzsche. Trata-se da ideia heideggeriana de que a metafísica identifica-se com a onto-teo-logia. Isto não significa que aceitaremos o modo como Heidegger pensa a ressignificação da divindade à luz de seu conceito de metafísica. Como veremos ainda que brevemente, a ideia de que a divindade (último Deus, Deus dos deuses, deidade dos deuses) se inscreve na amplitude da verdade do seer (Seyn), ainda que possa caracterizar

\footnotetext{
1 Nas palavras de Nietzsche: "Estamos ainda, talvez, demasiado sob as consequências mais próximas desse acontecimento [a saber, da morte de Deus] - e essas consequências mais próximas, suas consequências para nós, não são, ao inverso do que talvez se poderia esperar, nada tristes e ensombrecedoras, mas antes são como uma nova espécie, difícil de descrever, de luz, felicidade, facilidade, serenidade, encorajamento, aurora... de fato, nós filósofos e "espíritos livres" sentimo-nos, à notícia de que "o velho Deus está morto," como que iluminados pelos raios de uma nova aurora; nosso coração transborda de gratidão, assombro, pressentimento, expectativa - eis que enfim o horizonte nos aparece livre outra vez, posto mesmo que não esteja claro, enfim podemos lançar outra vez ao largo nossos navios, navegar a todo perigo, toda ousadia do conhecedor é outra vez permitida, o mar, nosso mar, está outra vez aberto, talvez nunca dantes houve tanto "mar aberto" (NIETZSCHE, 2002, § 343 - utilizamos aqui a tradução de Rubens Torres Rodrigues).
} 
a divindade como pertencente ao âmbito da retração do seer, transforma esta divindade em refém da horizontalidade do ser. Em outras palavras: a resolução heideggeriana da questão da ressignificação da divindade à luz do problema da onto-teo-logia ainda pensa a divindade por meio de algum condicionamento. Interessa-nos então levar adiante o horizonte semântico do conceito de onto-teo-logia e, à luz de alguns elementos que nele aparecem, pensar a possibilidade de a divindade se dar incondicionalmente, isto é, refratária a quaisquer horizontes de condicionamento de sua aparição. Para dar conta de tal tarefa, orientaremo-nos por duas vias de ressignificação não onto-teológica de Deus: as de Emmanuel Lévinas e Jean-Luc Marion. Tais pensadores, que explicitamente problematizam Deus a partir do conceito heideggeriano de onto-teologia, não submetem a divindade a qualquer ideia de horizonte condicionador de sua [de Deus] alteridade. Para que possamos dar conta do objetivo central do presente estudo - ressignificar o problema de Deus de modo não onto-teo-lógico, porém sem pensá-lo como subsumível a quaisquer horizontes condicionadores de sua aparição -, iremos seguir o seguinte percurso: 1) Caracterização do conceito heideggeriano de onto-teo-logia: aspectos gerais; 2) Deus como outro do ser em Lévinas ; 3) Marion e o Deus sem o ser; 4) Considerações finais.

\section{Caracterização do conceito heideggeriano de onto-teo-logia: aspectosgerais}

O conceito heideggeriano de onto-teo-logia surge com o intuito primário de caracterizar sua compreensão de metafísica. Dito sucintamente, Heidegger não entende por metafísica uma disciplina filosófica específica ou mesmo a doutrina segundo a qual o real é estruturado por duas instâncias ontologicamente distintas, uma de caráter meta-empírico (inteligível) e outra de caráter sensível. Para Heidegger, a metafísica caracteriza-se, antes de tudo, por interpelar o ser do ente a partir do ente, isto é, tomando como medida o ente e não a diferença irredutível entre ser e ente (diferença ontológica). Neste sentido, o ser do ente identifica-se com as propriedades estruturais do ente ou mesmo com o ente supremo fundador (ou causador) dos entes em geral, ente este compreendido como o mais ente dos entes. Respondendo à questão "que é o ente?" (tì tó òn), toda metafísica inquire o ente com vistas às propriedades simplesmente à vista (ou simplesmente dadas) que são passíveis de categorialização pelo pensamento (racional). Por isso, em Nietzsche II, Heidegger define a metafísica como pensamento que interpela "a verdade do ente enquanto tal e na totalida- 
de" (HEIDEGGER, 2008, p. 144). Em outras palavras: a metafísica pensa o ser como redutível a alguma propriedade ôntica ou como um ente específico, que funciona como condição de possibilidade do ente enquanto tal. Consequentemente, a metafísica perfaz-se por meio do esquecimento da irredutível diferença entre ser e ente. Ora, o que isto tem a ver com Deus? Como é possível que Heidegger caracterize toda e qualquer metafísica como onto-teo-lógica? Mais: como Deus se caracteriza metafisicamente, segundo Heidegger? As respostas a estas questões devem levar em conta o que Marion assinalou como as "duas funções cruzadas e recíprocas" (VR, p. 78) da onto-teo-logia ${ }^{2}$. Essas duas funções da onto-teo-logia nada mais são que a bidirecionalidade da metafísica tal qual pensada por Heidegger. Adiantando o que deveremos caracterizar com mais detalhes, em toda metafísica, há a interpelação do ser do ente com vistas aos elementos comuns de todo e qualquer ente e a inquirição do mais ente dos entes (maximamente ente), o ente supremo, como sentido último (causal ou fundacional) dos entes em geral. Vejamos um texto paradigmático de Identidade e diferença ("A constituição onto-teo-lógica da metafísica"), em que Heidegger assinala genericamente o que se entende por onto-teo-logia:

\begin{abstract}
A metafísica pensa o ente enquanto tal, quer dizer, em geral. A metafísica pensa o ente enquanto tal, quer dizer, no todo. A metafísica pensa o ser do ente, tanto na unidade exploradora do mais geral, quer dizer, do que em toda parte é in-diferente, como na unidade fundante da totalidade, quer dizer, do supremo acima de tudo. Assim é previamente pensado o ser do ente como fundamento fundante. Por isso, toda metafísica é, basicamente, desde o fundamento, o fundar que presta contas do fundamento; que lhe presta contas e finalmente lhe exige contas (HEIDEGGER, 1973, p. 393).
\end{abstract}

"A metafísica pensa o ente enquanto tal, quer dizer, em geral. A metafísica pensa o ente enquanto tal, quer dizer, no todo." O que estas duas frases signifi-

2l'être; ED: Étant donné; ID: L'idole et la distance; MDND: “De la 'mort de Dieu' aux noms divins: l'itinéraire théologique de la metaphysique"; $\mathrm{AD}$ : Acerca de la donación: una perspectiva fenomenológica. Livros de Lévinas: DMT: Deus, a morte e o tempo; EN: Entre nós: Ensaios sobre a alteridade; TI: Transcendência e Inteligibilidade; DVI: De Deus que vem à ideia; AE: $A u$ trement qu'être ou au-delà de l'essence; EI: Ética e Infinito; IH: Los imprevistos de la historia; TI: Totalidade e infinito; TA: Transcendência y altura; Trans. Int: Transcendência e Inteligibilidade. 
cam pode ser compreendido se levarmos em conta o fato de que, historicamente, a metafísica não inquire uma região do real, mas interpela a totalidade do ente, com o intento de elencar os caracteres estruturais de todo e qualquer ente. Neste sentido, o arcabouço conceitual produzido pelo questionamento metafísico possui pretensão de universalidade. Noções como essência, existência, substância, acidente, matéria, forma, dentre outras, possuem caráter universal. Por isso, tais noções condicionam nossa compreensão dos entes e nossos comportamentos diante deles. Ora, devido a esta universalidade, a metafísica "pensa o ser do ente, tanto na unidade exploradora do mais geral, quer dizer, do que em toda parte é in-diferente", ou seja, a metafísica, ao pensar os caracteres gerais que determinam todo e qualquer ente, pensa o que é "in-diferente", isto é, noções que só aparecem para o pensamento quando este é indiferente à particularidade dos entes que efetivamente existem no real. Contudo, a onto-teo-logia não somente investiga o mais geral: ela pergunta pela "unidade fundante da totalidade, quer dizer, do supremo acima de tudo". Trata-se, como já mencionado, da pergunta pelo mais ente dos entes, que concentra em si o máximo de entidade e a razão última de ser de tudo que é. Deste modo, a totalidade dos entes não possui seu fundamento em algo que lhes é intrínseco. Os conceitos gerais provenientes da metafísica não explicam por si sós a raiz derradeira dos entes. Se o mais ente dos entes é irredutível aos entes abarcados pelos conceitos universais elencados pela ontologia, isto equivale a dizer que o ente supremo é particularíssimo, ou seja, para concebê-lo, não é possível abstrair-se de sua condição particular, como fazemos com os demais entes, quando, por meio de uma lida abstrativa, deles arrancamos conceitos genéricos que permitem dar conta daquilo que lhes é comum. O problema da metafísica é justamente o de pensar a seguinte unidade: como pode a metafísica, ao mesmo tempo, pensar o mais geral e o mais singular? Como problematizou Marion:

Com efeito, a dificuldade principal da ciência metafísica está no caráter problemático de sua unidade: como a mesma e única (una et eadem) ciência pode ao mesmo tempo (simul) tratar do ente comum (portanto de nenhum em particular) e do ente por excelência (portanto de um ente supremamente particular)? Certamente, trata-se de dois casos de uma abstração, mas tomada em duas acepções inversas: num caso, uma abstração relativamente a todo ente real, portanto uma abstração somente de razão; no outro caso, uma abstração em vista 
do ente tanto mais concreto que nenhuma materialidade o afeta, portanto uma abstração real. (VR, p. 78)

A tradição metafísica, desde o século XVIII, entendeu que a metafísica dividese em metafísica geral (ontologia, estudo do ente comum) e metafísica especial, esta subdividida em teologia racional (ou teologia natural), psicologia racional e cosmologia (Cf. Ibidem, p. 76-77). Exatamente esta divisão parece dar conta da bidirecionalidade essencial à metafísica, como a pensou Heidegger. Contudo, o problema vislumbrado por Marion é o da unidade dessas duas direções da metafísica. Não se trata de uma relação de justaposição entre a metafísica que pensa o ente e a metafísica que pensa o ente supremo acima de tudo. Isto seria pensar duas metafísicas que se articulam extrinsecamente. Como já foi afirmado, a metafísica em sua unidade se determina de modo simultaneamente bidirecional. Uma só e única metafísica pensa o ente geral e o ente supremo. Ora, neste caso, a copertinência de ontologia (pensamento do ente comum) e teologia (pensamento do supremo acima de tudo) se dá por mútua fundamentação: “A unidade deste um é de tal natureza que o último [Deus], a seu modo, fundamenta o primeiro [ente enquanto tal em sua generalidade] e o primeiro, a seu modo, fundamenta o último" (HEIDEGGER, 1973, p. 395). Tratase, então, de uma mútua fundamentação: o que a tradição moderna chamou de metafísica geral (ontologia) funda a teologia natural e a teologia natural funda a metafísica geral. Ou, nas palavras de Marion: "O ser comum funda os entes mesmo excelentes; em retorno o ente por excelência funda pelo modo da causalidade o ser comum” (VR, p. 79). Esta dupla fundamentação cruzada explica-se, segundo Heidegger, pelo fato de a onto-logia e a teo-logia (natural) serem "logias", ou seja, direcionamentos ou vias de o lógos fundamentador se determinar: "A 'logia' é, cada vez, o todo de um complexo fundador, onde os objetos das ciências são representados sob o ponto de vista de seu fundamento, isto é, são compreendidos. A ontologia, porém, e a teologia são 'logias' na medida em que exploram o ente enquanto tal e o fundam no todo" (HEIDEGGER, 1973, p. 394). Em outras palavras: o lógos da ontoteo-logia funciona como 'complexo fundador", uma vez que a fundamentação de todo e qualquer ente se dá por meio do acontecimento simultâneo e copertinente de ontologia e teologia. O que se entende pela dupla fundamentação cruzada de ontologia e teologia pode ser compreendido retamente, se levarmos em conta o fato de que Deus funda derradeira e ontologicamente a totalidade do ente e os conceitos gerais presentes na ontologia fundam conceitualmente o que se entende por Deus. Disto se depreende que os caracteres gerais dos entes garantem inteligibilidade ao Deus metafísico e o Deus metafísico responde pela inteligibi- 
lidade última dos entes. Por causa deste círculo fundacional, tudo que é e pode ser ganha legitimidade. Contudo, tal relação circular encontra em Deus a causa última dos próprios caracteres dos entes que servem para compreender o que ele [Deus] é. ${ }^{3} \mathrm{O}$ que, então, se entende por Deus neste pensamento? Vejamos a resposta de Heidegger:

como a causa prima, que corresponde à volta fundamentante à ultima ratio, ao último prestar contas. $\mathrm{O}$ ser do ente somente é representado radicalmente, no sentido do fundamento, como causa sui. Com isto designamos o conceito metafísico de Deus. A metafísica deve ultrapassar, com seu pensamento, tudo em direção de Deus, pelo fato de que o objeto do pensamento é o ser; este, porém, se torna fenômeno de múltiplas maneiras, enquanto fundamento: como lógos, como hypokeímenon, como substância, como sujeito" (Idem).

Segundo o texto acima, Deus aparece como "objeto originário do pensamento". Mais: Deus aparece, na onto-teo-logia, como ser do ente "representado radicalmente". Isto significa que a metafísica atinge o ápice de seu desenvolvimento, quando atinge o sentido último do ser do ente, que se identifica com Deus. Neste sentido, o objeto originário do pensamento é o sentido último doser do ente. Este, contudo, aparece segundo a categoria da causalidade. Por um lado, Deus é última razão (ultima ratio), ou seja, é aquele para qual o ente presta derradeiramente contas. A última razão é, em outros termos, o último fundamento do ente. Em meio à busca pela fundamentação do ente, Deus aparece como fundamento supremo. Entretanto, o que aqui significa fundamento último nada mais é que a causa primeira do todo. Por isso, o objeto originário do pensamento é a causa primeira da totalidade. Deus é, primeiramente, causa do que ele mesmo não é. Esta consideração não é conclusiva. Heidegger pensa a causalidade divina também em um outro sentido: Deus não é somente causa

3 Vale a pena reproduzir as palavras de Marion que sintetizam este pensamento: “(...) em sua constituição onto-teo-lógica, uma metafísica se organiza segundo os múltiplos sentidos de uma única fundação; pois é a partir da fundação que se definem seus dois termos - seja a fundação conceitual (Gründung) dos entes no ser, seja a fundação causal e segundo a razão suficiente (Begründung) dos entes por um ente por excelência. Mais ainda, a esta única fundação corresponde também vincular entre elas as duas fundações cruzadas, conceitual e causal: com efeito, se acontece que o ser mesmo se ache fundado por um ente supremo (e não somente os entes), é porque este último consuma o ser realizando exemplarmente seus caracteres de ser em geral de todos os entes, quer dizer, efetuando seu ser possível” (DSE, p. 284). 
primeira dos demais entes; ele é causa de si. O sistema de fundamentação divina pressupõe um movimento de auto-fundamentação por parte de Deus. Ainda que o conceito de causa sui dependa diretamente do pensamento cartesiano e tenha repercussão imediata em Spinoza (por exemplo, a primeira proposição da Ética diz: "Por causa de si [Per causam sui] compreendo aquilo cuja essência envolve a existência, ou seja, aquilo cuja natureza não pode ser concebida senão como existente" (SPINOZA, 2007, Def.1), o que interessa a Heidegger com tal conceito é o fato de o Deus metafísico se assegurar de si a cada vez que fundamenta os demais entes. Este auto-asseguramento permite a Deus fornecer à totalidade sua permanência ontológica. Por isso, Heidegger afirma que lógos, hypokeímenon, substância e sujeito podem funcionar como Deus. Isto porque lógos, hypokeímenon, substância e sujeito precisam, antes de fundamentar o que quer que seja, assegurar-se de si próprios como índices de fundamentação da totalidade. Tal movimento reflexivo é o sentido do conceito de causa de si, segundo Heidegger.

A condição de possibilidade de Deus como causa de si é o esquecimento da diferença ontológica, isto é, a diferença entre ser e ente, diferença esta que não permite pensar o fundamento do ente como a-histórico, uma vez que o seer (Seyn) acontece como abertura do ente na totalidade, que, por não possuir fundamentos últimos, possui caráter histórico. ${ }^{4}$ Se por um lado o seer descerra um horizonte histórico no qual tudo que é e pode ser se estabelece, por outro, à medida que ele não possui fundamentação última (não é reificado), ele mesmo se retrai no abismo (o sem fundo) de sua diferença em relação ao horizonte que ele mesmo desvela (Cf. CASANOVA, 2014). O seer acontece, portanto, diferindo-se daquilo que ele mesmo estabelece. ${ }^{5} \mathrm{O}$ esquecimento desse movimento de diferenciação do seer no estabelecimento de um mundo histórico (época) é, para Heidegger, a raiz da onto-teologia.

$4 \mathrm{O}$ tradutor brasileiro da obra heideggeriana Marco Antônio Casanova traduz o verbo Seyn utilizado por Heidegger com a grafia alemã antiga por seer, do mesmo modo como o verbo ser era escrito na língua portuguesa, por exemplo, no século XIX. Tal mudança de grafia, em Heidegger, visa a deixar claro que o seer não é o ser do ente tal qual pensado pela metafísica, isto é, a presença constante que fundamenta todo devir dos entes em geral, presença esta que, em última instância, identifica-se com a noção metafísica de Deus. Seer se determina como acontecimento histórico de mundo e, pelo fato de todo mundo ser histórico, o seer ele mesmo retrai-se no abismo de sua diferença. Seer, consequentemente, como ainda deve explicitado, diz respeito à diferença ontológica, tal qual esta é pensada na obra tardia de Heidegger. Levaremos em consideração esta tradução de Seyn por Seer, na presente investigação.

5 Não iremos, aqui, nos aprofundar neste tema. Devemos, contudo, lembrar que o conceito que responde por esta dinâmica acontecimento do seer, que funda um horizonte histórico globalizante e se retrai no momento mesmo que descerra tal fundamento, é o de acontecimento apropriador (Ereignis), conceito chave do que pode ser considerada a mais importante obra de Heidegger depois de Ser e tempo, o livro Contribuições à filosofia (Do acontecimento apropriador). Cf. HEIDEGGER, 2015. 
Em outras palavras: a metafísica pensa o ser do ente onto-teo-logicamente porque pensa o diferente da diferença. Como afirma Heidegger: "Na medida em que a metafísica pensa o ente enquanto tal, no todo, ela representa o ente a partir do olhar voltado para o diferente da diferença, sem levar em consideração a diferença enquanto diferença" (HEIDEGGER, 1973, p. 398). Se o ente é explicado por meio desse Deus, fato é que diante dele não há como instaurar comportamentos que assinalem a repercussão existencial de todo ato efetivamente religioso. Por isso a clássica observação heideggeriana: “A este Deus [o Deus da metafísica] não pode o homem nem rezar, nem sacrificar. Diante da causa sui, não pode o homem nem cair de joelhos por temor, nem pode, diante deste Deus, tocar música e dançar” (Ibidem, p. 399).

Se Heidegger caracteriza a onto-teo-logia como lugar onde historicamente Deus perdeu "vitalidade", isto significa primeiramente que a ressignificação não metafísica de Deus deve prescindir da noção de causalidade (eficiente e final, sobretudo), além da ideia de que os caracteres ontológicos gerais depreendidos dos entes funcionam como causas conceituais do ser divino. Isto porque, deste modo, a divindade aparece condicionada por regimes conceituais e ontológicos que posicionam seu ser e determinam a priori o seu modo de manifestação. Ora, se levarmos em conta que, conforme o que fora afirmado, a noção de diferença ontológica explicita o modo de o seer descerrar mundos históricos que condicionam os entes em geral, a incondicionalidade da divindade deve ser irredutível à questão da horizontalidade do seer, ainda que o seer se retraia no abismo de sua diferença. A razão disso é uma só: a retração do seer desfundamenta o mundo, para assegurar a possibilidade de novos mundos (isto é, de novos fundamentos históricos). Logo, o seer se retrai para que outros horizontes de descerramento e condicionamento dos entes sejam possíveis. Por isso, a retração do seer está "a serviço" de novos condicionamentos do que quer que seja, inclusive da divindade, uma vez que, segundo Heidegger, somente à luz da questão do seer é possível pensar um lugar para Deus. ${ }^{6}$ De modo contrário, em Lévinas e Marion, Deus aparece irredutível ao seer. Vejamos.

\footnotetext{
6 Isto aparece claramente na Carta sobre o humanismo, quando Heidegger afirma: "É só a partir da verdade do ser que se pode pensar na essência do sagrado. E é só a partir da essência do sagrado que se pode pensar a deidade. É só à luz da essência da deidade que se pode pensar e dizer o que deve nomear a palavra 'Deus'. Ou não será necessário que possamos compreender e ouvir todas essas palavras com cuidado se quisermos, como homens, isto é, como seres ek-sistentes, poder experimentar uma relação de Deus com o homem. Pois como deve o homem que pertence à história universal da atualidade poder ao menos perguntar com seriedade e rigor se Deus se aproxima e se subtrai, quando ele mesmo negligencia adentrar primeiramente e pensar a única dimensão na qual aquela questão pode ser colocada? Esta é, porém, a dimensão do sagrado, a qual, quiçá já como dimensão, permanece vedada, se o aberto do ser não for iluminado e não tiver próximo do homem em sua clareira" (HEIDEGGER, 2008, p. 364). Sem o horizonte do seer, Heidegger não vê possibilidade de se colocar a questão de Deus. Consequentemente, Deus é condicionado ontologicamente: fora do seer, ele nada pode ser.
} 
Dr. Alexandre Marques Cabral

[UER]]

\section{Deus como outro do ser em Lévinas}

A questão de Deus aparece na obra levinasiana diretamente ligada ao conceito heideggeriano de onto-teo-logia. Por um lado, Lévinas depende do modo como Heidegger pensa a metafísica como onto-teo-logia para reposicionar a questão de Deus. Por outro, ele contrapõe-se à ressignificação heideggeriana do conceito de Deus. Por isso, encontra-se, na abertura de outro modo que ser ou para além da essência, a seguinte afirmação: "Mas, entender um Deus não contaminado pelo ser é uma possibilidade humana não menos importante e não menos precária que a de retirar o ser do esquecimento onde teria caído na metafísica e na onto-teo-logia" (AE, p. 10). Uma afirmação como esta chama inicialmente atenção pelo fato de Lévinas querer dissociar a questão de Deus da questão do ser (Seinsfrage). Por este motivo Deus aparece como refratário à ontologia pensada por Heidegger, assim como à ontoteo-logia também pensada por ele. Apesar de a questão do esquecimento do seer, questão heideggeriana por excelência, ter se tornado problema central no pensamento filosófico contemporâneo, Lévinas quis assinalar que a disjunção entre Deus e ser, inclusive no que concerne ao seer heideggeriano, deve ganhar notoriedade. Contudo, se essa passagem de outro modo que ser ou para além da essência não deixa aparecer a dependência levinasiana do conceito heideggeriano de onto-teo-logia, no início da segunda parte de Deus, a morte e o tempo, isto se torna evidente: "Também aqui se trata de acabar com a onto-teo-logia. Mas uma questão se levanta: terá a falta da metafísica consistido em tomar o ser por Deus - ou antes em tomar Deus pelo ser?" (DMT, p. 148). Mais a frente, Lévinas questiona: "Não significará Deus o outro do ser? (...) Opor Deus à onto-teo-logia é conceber uma nova maneira, uma nova noção de sentido. E é de uma certa relação ética que se pode partir para uma tal procura" (Ibidem, p. 148-149). Citações como essas nos permitem dizer que a assunção levinasiana da onto-teo-logia e sua recusa da resolução heideggeriana acerca da questão da divindade desemboca em uma tentativa de superação ética da onto-teologia, superação esta que ressignifica o problema de Deus desarticulando a divindade da noção de ser. Como isso se dá? Como Lévinas recusa o problema heideggeriano do seer (Seyn) e, por meio disso, almeja repensar a questão de Deus? Por que Lévinas pensa que opor Deus à onto-teo-logia exige reposicionar a questão do sentido?

A dissociação levinasiana de Deus e ser (Deus como outro do ser) é signo da sua crítica radical à ontologia. Esta crítica não nasce arbitrariamente, mas ela mesma é sinal da intuição fundamental de Lévinas segundo a qual a tradição filosófica ocidental (e a cultura ocidental em geral) nasce juntamente com a 
hegemonia do regime de verdade do mesmo, em detrimento da alteridade (o outro). De um modo ainda impreciso, é possível entender a categoria do mesmo como o que "é idêntico a si" (Ibidem, p. 161). O que Lévinas entende como "idêntico a si" diz respeito à absoluta autorreferencialidade do mesmo. Por ser autorreferencial, tudo que aparece para ele aparece segundo a sua [do mesmo] medida. Neste sentido, tal conceito assinala sua significatividade à luz daquilo que se lhe contrasta: o outro. O mesmo só é o que é por meio da anulação da alteridade do outro. Em outras palavras: o mesmo é a categoria filosófica que assinala toda dinâmica tautológica (tudo que é é segundo o mesmo e possui a identidade fornecida pelo mesmo e, por isso, só espelha o que o mesmo é) de subsunção da alteridade do ente à imanência de sua respectiva medida. Enquanto medida englobante da alteridade, o mesmo é total, isto é, possui a pretensão de ser omniabarcante. Por esse motivo, a categoria do mesmo identifica-se com a noção de totalidade. Ambas são categorias que mutuamente se explicitam. O mesmo realiza-se como totalidade e a totalidade só se presentifica segundo a dinâmica da mesmidade. Conforme afirma Ricardo Timm de Souza: "totalidade é, assim, a realização da dinâmica do Mesmo, a síntese final das energias que integram o Outro a uma unidade sólida" (SOUZA, 2004, p. 169). Se o regime de verdade do mesmo é o regime hegemônico da cultura ocidental; se este regime se atualiza por meio da subsunção da alteridade pela imanência de seu [do mesmo] horizonte de constituição, então, paradigmas políticos, valores morais, práticas pedagógicas, teorias filosóficas e teológicas etc. podem ser índices desta hegemonia. Contudo, Lévinas interessa-se sobretudo pelas vozes filosóficas desta hegemonia, o que o levou a elucidar como, no desdobramento histórico da filosofia, suas mais diversas vozes salvaguardam uma determinada medida una que sinaliza a força do regime da totalidade ao longo do seu curso. Duas passagens de duas obras levinasianas nos auxiliam a compreender o modo como o regime de verdade da totalidade se estabeleceu na filosofia:

Enquanto saber, o pensamento é o modo pelo qual uma exterioridade se encontra no interior de uma consciência que não cessa de se identificar, sem ter de recorrer para tal a nenhum signo disjuntivo e é Eu: o Próprio. O saber é uma relação do Próprio com o Outro onde o Outro se reduz ao Próprio e se despoja da sua alienidade, onde o pensamento se refere ao outro, mas onde o outro já não é outro enquanto tal, onde ele é já o próprio, já meu. (Trans. Int, p. 14) 
O acontecimento ontológico que se realiza na filosofia consiste em suprimir ou em transmutar a alteridade do todo Outro, em universalizar a imanência do Mesmo ou a Liberdade, em apagar as fronteiras, em expulsar a violência do Ser.

O Eu cognoscente é o crisol de tal transmutação. É o Mesmo por excelência. Quando o Outro entra no horizonte do conhecimento, já renuncia a alteridade. (TA, p. 87).

"Enquanto saber, o pensamento é o modo pelo qual uma exterioridade se encontra no interior de uma consciência que não cessa de se identificar, sem ter de recorrer para tal a nenhum signo disjuntivo e é Eu: o Próprio." O que Lévinas entende, nesse contexto, por "saber" identifica-se com o saber filosófico historicamente hegemônico, que dá voz à lógica tautológica do mesmo, em detrimento da alteridade do outro. Ora, como fica claro nessa passagem, o saber é anulador do caráter de exterioridade da alteridade. Ser outro significa, neste caso, ser externo à medida tautológica da totalidade. Se o saber reduz esta alienidade à imanência do mesmo, é porque o saber nada mais faz que determinar-se por uma dinâmica assimilatória. Saber é inscrever a alteridade do ente na amplitude da medida do mesmo e, por consequência, tornar o ente disponível para esta mesmidade. O índice de realização do saber é chamado por Lévinas, à luz de um termo caro para a filosofia moderna, de consciência. Como deixa claro Lévinas, a consciência incessantemente identifica a si mesma como lugar de significação do que quer que seja. Somente assim a lógica tautológica do mesmo se potencializa e os processos assimilatórios do outro se concretizam. Por isso, o que resulta dessa lógica assimilatória é a possessividade (ser meu) da alteridade pela consciência (próprio). Disto deriva a passagem acima de Transcendência e Altura: “O Eu cognoscente é o crisol de tal transmutação. É o Mesmo por excelência. Quando o Outro entra no horizonte do conhecimento, já renuncia a alteridade." Em outras palavras: conhecer é anular a alteridade do outro e forçá-la a se reduzir à amplitude do horizonte de atuação do mesmo. Tal amplitude, por possuir finitude, caracteriza-se por ser uma totalidade limitada, de onde advém o sentido do conceito de totalidade anteriormente assinalado. Ora, esta dinâmica assimilatória própria da consciência se repete na ideia heideggeriana de seer. Por isso, ao ressignificar a questão de Deus, por almejar pensálo como irredutível a qualquer horizonte assimilatório, Lévinas deverá entendê-lo de outro modo que ser, isto é, como o outro do ser. Para compreender essa questão, é preciso, antes de tudo, perguntar: por que Lévinas não leva adiante o projeto ontológico de Heidegger? Como é possível pensar Deus e também a consciência desvinculados de quaisquer ideias de horizonte? 
Lévinas entende a ideia heideggeriana de seer (devedora do conceito de diferença ontológica) à luz do conceito de essência. Por isso, no início de outro modo que ser ou para além da essência, Lévinas afirma: "O termo essência significa aqui o ser distinto do ente, o Sein alemão enquanto distinto do Seiendes, o esse latino como distinto do ens escolástico" (AE, p. 9). A distinção entre seer e ente é, como vimos, uma distinção de matriz heideggeriana: a diferença ontológica. Esta diferença assinala, como já dito, o fato de o seer (irredutível ao ente) descerrar o campo de aparição e condicionamento do ente, retraindo-se no abismo de sua diferença. Neste sentido, o seer dá-se como um englobante, isto é, um horizonte (global) de posicionamento do modo de ser dos entes em geral. Como diz Heidegger, em Contribuições à filosofia: "O seer se essencia; o ente é" (HEIDEGGER, 2015, § 139). Se a essê-ncia (ou essância, como por vezes afirma Lévinas) é o exercício do esse (seer), isto significa que Lévinas está pensando a sempiternidade ou a constante retomada do seer em seu ímpeto posicionador de todo e qualquer ente. Ora, se tudo que é depende do exercício posicionador do seer, este aparece como princípio (ontológico) absoluto, ou seja, aquilo para além do qual nada há. É o seer que fornece a identidade de todo ente, o que permite-nos considerá-lo como horizonte identitário por excelência, já que a auto-manifestação do seer reconduz toda alteridade dos entes à sua medida identitária. Nada do que resiste ao horizonte identitário do seer possui alguma dignidade ontológica. Em outras palavras: o que resiste ao seer não é. Ao delimitar o modo de ser dos entes, a essência anula a alteridade do ente enquanto tal. Esta subsunção da alteridade do ente pelo seer, segundo Lévinas, aparece claramente na ideia heideggeriana de compreensão. Neste caso, a compreensão descerra o horizonte dentro do qual a singularidade do ente se revela. Se o ser (na época de Ser e tempo, Heidegger o escreve com “i”: Sein) só aparece por meio dos processos compreensivos do ser-aí (Cf. HEIDEGGER, 2006, § 29) e, assim, o mundo enquanto horizonte de descerramento da totalidade do ente se desvela, então, o ser, enquanto horizonte iluminador de todo e qualquer ente, aparece subsumindo todo ente pela sua medida (luz). Como afirma Lévinas:

Heidegger descreve assim, na sua estrutura mais formal, as articulações da visão em que a relação do sujeito com o objeto é subordinada à relação do objeto com a luz - a qual não é objeto. A inteligência do ente consiste então em ir para além do ente - precisamente no aberto - e em percebê-lo no horizonte do ser. Equivale a dizer que a compreensão, em Heidegger, logra alcançar 
a grande tradição da filosofia ocidental: compreender o ser particular já é colocar-se além do particular - compreender é relacionar-se ao particular, único a existir, pelo conhecimento que é sempre conhecimento do universal (EN, p. 26).

Porquanto o que Lévinas entende por essência outra coisa não é senão o exercício do esse, isto é, do seer; se a essência produz a recondução do particular (singular) ao universal, então, a afirmação da alteridade exige a desconstrução da hegemonia da ontologia. Como Lévinas afirmou em passagem anteriormente reproduzida: "O acontecimento ontológico que se realiza na filosofia consiste em suprimir ou em transmutar a alteridade do todo Outro, em universalizar a imanência do Mesmo ou a Liberdade, em apagar as fronteiras, em expulsar a violência do Ser." A ruptura com a violência do seer se dá por meio da afirmação do outro, isto é, daquele que a totalidade (seja intrínseca à noção tradicional de consciência ou característica de toda e qualquer ontologia) visa a subsumir. Somente por meio da ruptura com o mesmo é possível reinscrever Deus na filosofia fora do regime de verdade da totalidade. Isto porque Deus tornou-se refém da mesmidade, sobretudo por causa das ontologias. Em De Deus que vem à ideia, Lévinas afirma: “O discurso filosófico deve, portanto, poder abranger Deus - de que fala a Bíblia - se tem um sentido. Mas, pensado, Deus se situa imediatamente no interior da 'gesta de ser"' (DVI, p. 86-87). Do que fora afirmado, então, é pertinente afirmar que seer, totalidade e mesmidade passam a identificar-se ao longo do pensamento ocidental e, por isso, Deus torna-se refém da ditadura dos horizontes ontológicos de posicionamento dos entes em geral ou das figuras históricas da consciência posicionadora. Por isso, se Deus foi capturado pelo mesmo, devemos colocar as seguintes questões: como se pode libertar Deus da ontologia? Como é possível deixar Deus ser Deus "fora" da mesmidade ou "de outro modo que ser"?

A reinscrição de Deus nos átrios da filosofia e da teologia de modo não ontoteo- lógico, isto é, sem ser englobado pelo mesmo só pode ser realizada através da reabilitação da ideia de transcendência (Cf. DMT, II parte). Esta, contudo, não pode ser pensada segundo a dicotomia platônica sensível/inteligível, ou seja, como diferenciação e separação de dois planos ontológicos qualitativamente distintos, de tal modo que o deslocamento ascendente do sensível para o inteligível identificar-se-ia com a noção de transcendência. Por este motivo, Lévinas apropria-se da ideia de transcendência à luz da irredutibilidade do outro 
ao mesmo. Transcendente é a exterioridade ou alienidade do outro em relação à imanência do horizonte globalizante da totalidade. Daí a sua caracterização da transcendência: "Esta [a transcendência] designa uma relação com uma realidade infinitamente distante da minha, sem que essa distância destrua por isso esta relação e sem que esta relação destrua essa distância, como aconteceria para as relações dentro do Mesmo" (TI, p. 29). Dito de outro modo, a transcendência assinala a dignidade da alteridade, que, ao se dar, não é passível de ser assimilada ao mesmo, uma vez que sua distância preserva sua irredutibilidade ante os limites da totalidade. Não somente isto. Lévinas quer, por meio do conceito de transcendência, desconstruir seu sentido ascético, cujo pressuposto, no mais das vezes, está assentado na ideia de fuga da imanência histórico-temporal. Nesta ideia, há uma clara operacionalização do conceito de negatividade como sentido do ato de transcendência: a negação da realidade espaçotemporal promoveria a ascensão para a transcendência. Ao rejeitar esta compreensão, Lévinas pretende correlacionar transcendência e estrangeiridade. A alteridade é o estrangeiro, no sentido de que ela excede toda totalidade e jamais irá se domesticar em um horizonte específico. Por isso, Lévinas diz que a transcendência é "passagem ao outro, ao absolutamente outro" (Idem).

Se a alteridade é transcendente; se a transcendência não é uma região ontológica; se a transcendência se caracteriza por distanciar-se (absolutamente) do mesmo, então, é possível afirmar que, na ideia levinasiana de transcendência, há uma ligação direta com a ideia de infinito. Primeiramente, isto fica claro pelo fato de a alteridade ser irredutível ao caráter finito da totalidade. Relembrando o que fora dito, a noção de totalidade sobrevive por causa das bordas de sua finitude. Por isso, é paradoxal o fato de que, ainda que finita, a totalidade almeje condicionar de modo omniabarcante todo ente e toda experiência. Mais: a totalidade conquista sua força de posicionamento dos entes por meio do obscurecimento da sua finitude. ${ }^{7}$ Com a aparição da alteridade, a totalidade sofre um trauma em sua dinâmica de autoposicionamento. Isto significa que a alteridade des-totaliza o mesmo, rompe a finitude da totalidade, isto é, a alteridade se dá como in-totalidade ou in-finito. Como afirma Souza: "A in-totalidade, a 'infinitude' da totalidade, significa in-completação, suspensão da dinâmica de completação, negação do 'encontrar-se consigo mesmo' ínsito a todo processo de totalização possível” (SOUZA, 2004, p. 170).

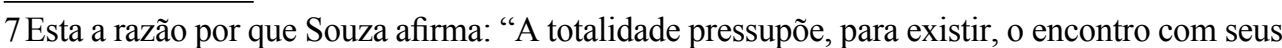
próprios limites. Este é seu paradoxo definitivamente invalidante, aquilo que invalida, mesmo desde um exame meramente 'interno' de suas condições de possibilidade, sua (auto) compreensão. Pois, para ser total, a totalidade tem de chegar até seus limites; mas, ao chegar até eles, não é total, pois os reconhece, exatamente, como seus limites." (SOUZA, 2004, p 170) 
Consequentemente, alteridade e infinito se conjugam essencialmente. Como diz Lévinas: "a ideia do infinito designa uma altura e uma nobreza, uma transcendência" (TI, p. 29). Entretanto, o infinito por ele pensado deriva de uma apropriação criativa da ideia de infinito presente nas Meditações metafísicas, de Descartes. Por isso, o infinito é Deus. Ora, tal conceito não nasce da negação proposicional dos caracteres finitos presentes nos entes temporais por meio de um processo gnosiológico abstrativo. Infinitude não é um conceito que surge dos processos representacionais da subjetividade humana. Levando adiante Descartes, Lévinas diz: “A noção cartesiana da ideia do Infinito designa uma relação com um ser que conserva a sua exterioridade total em relação àquele que o pensa. Designa o contato do intangível, contato que não compromete a interioridade daquilo que é tocado" (Ibidem, p. 37). Exatamente o caráter formal desta ideia cartesiana do infinito em nós identifica-se com a ideia levinasiana de Deus. Disto surge imediatamente o seguinte percurso de pensamento: porquanto a alteridade só aparece na transcendência e esta identifica-se com o infinito, o problema levinasiano de Deus conjuga-se com a questão do outro. Mas, que outro é esse? De que alteridade se trata? Que alteridade é esta que traumatiza a totalidade e não é por ela absorvida, preservando sua irredutível distância (altura) ante os limites do mesmo? Resposta: "A questão do Outro converte-se em responsabilidade para com outrem, e o temor de Deus - estranho tanto ao pavor ante ao sagrado quanto à angústia diante da morte - em temor para com o próximo e sua morte" (DVI, p. 164).

Deus acontece (eticamente), por meio da aparição não objetiva do rosto de outrem. O que torna o outro meu próximo não é o fato de ele estar geograficamente perto. Estar perto não é ser próximo. Próximo é o modo de outrem se dar como quem é. Por isso, a proximidade se caracteriza pela irrupção do rosto, rosto este que nada tem a ver com a fisionomia facial de alguém. Antes, o rosto se dá na irredutibilidade de outrem aos processos compreensivos do ser humano, ou seja, o rosto é o que em outrem resiste às investidas de totalização da consciência, razão pela qual, em De Deus que vem à ideia, Lévinas chega a dizer: "O rosto está presente na sua recusa de ser conteúdo. Neste sentido, não poderá ser compreendido, isto é, englobado" (DVI, p. 173). Se o rosto é inabarcável compreensivelmente, então, a alteridade que se dá no rosto de outrem conjuga o conceito de outro com a noção de assimetria, uma vez que o outro é absolutamente refratário a quaisquer medidas horizontais de condicionamento de sua (auto) manifestação; por isso, não há medidas que possam mensurar qualquer relação de proporcionalidade entre mim e o outro. Dito de outro modo: o outro 
não é alguém igual a mim. Ele não é, portanto, análogo ao que sou, nem uma particularização de uma essência que me é comum. Inabarcável pela mesmidade (ser, essência), assimétrico e impossível de ser comparado por quaisquer medidas analógicas, o rosto, ao se expor, não possui a força das substâncias ou a estabilidade das essências. Sua irrupção assinala sua fragilidade. Ele é "sem defesa", pois possui "uma pobreza essencial” (EI, p. 77-78). Diante de outrem, sou impelido a responder pela sua fragilidade e entregar-me à sua mortalidade. Em outras palavras: a irrupção do rosto de outrem exige de mim uma responsabilidade absoluta por sua fragilidade. Ora, se é possível falar da fragilidade do rosto e de sua pobreza essencial, é porque o rosto, quando se dá, transmite alguma significatividade; o rosto diz algo de si, o que equivale a dizer que sua manifestação produz inteligibilidade. Trata-se, contudo, de uma "significação sem contexto" (Ibidem, p. 78) ${ }^{8}$, ou seja, de uma significação que não se determina à luz de uma relação com outra coisa que o rosto mesmo. Há portanto um significado que se dá com a auto-manifestação do rosto. Que significado é este? Em Ética e Infinito, Lévinas diz: “O Infinito vem-me à ideia na significância do rosto. O rosto significa o Infinito" (Ibidem, p. 97). Ora, se Lévinas entende Deus como o infinito e se este se dá por meio do rosto, isto quer dizer que, no rosto, deparamo-nos com a impossibilidade de a consciência reconduzir a divindade aos limites de suas visadas intencionais. Mais: se Deus se dá no significado do rosto e este significado não pode ser reconduzido aos limites do mesmo, então, Deus se dá de outro modo que ser, ou seja, fora da essência, fora do inter-esse: Deus se dá desinteressadamente (fora do esse), em um comprometimento ético com o rosto de outrem que nada visa senão responder por sua fragilidade. Somente em meio à ética, Deus aparece como outro do ser.

Com as informações anteriores, é possível dizer que Lévinas encontra filosoficamente a legitimidade de seu entendimento da relação entre o Deus judaico e o compromisso ético, pois segundo ele, no judaísmo, "a relação com Deus não se concebe em nenhum momento fora da relação com os homens" (IH, p. 174). Por isso, Deus se dá fora (exterior) do ser, isto é, irredutível a qualquer onto-teo-logia, em um compromisso infinito com a fragilidade do rosto mortal de outrem.

8 Apesar de Lévinas entender o "contexto" como uma significatividade que se dá na relação de um ente com outro ente, é possível, respeitando o "espírito" de suas considerações, dizer que uma significação contextual caracteriza-se por subsumir o ente a qualquer horizonte de sentido fornecedor das múltiplas possibilidades de significação dos entes em geral. 


\section{Marion e o Deus sem o ser.}

A ruptura marioniana com a onto-teo-logia e sua correlata ressignificação da questão de Deus aparece em consonância com a ideia de Deus sem o ser, expressão que tornou-se título de uma das mais conhecidas obras de Marion. Porquanto tal expressão nasce em sintonia plena com a tentativa de desconstrução da identificação de Deus com o regime de verdade onto-teo-lógico, não é possível entendê-la por meio da ideia metafísica de existência (existentia), entendida como o ato (actus) segundo o qual um ente é factivelmente vigente. "Sob o título de Deus sem o ser não intentamos insinuar que Deus não é, nem que Deus não seja verdadeiramente Deus (...) De outro modo, pretendemos tornar problemática esta evidência, sustentada pelos filósofos surgidos da metafísica e pelos teólogos surgidos do neo-tomismo: Deus, antes de qualquer outra coisa, tem de ser" (DSE, p. 10-11). O que significa esse "ter de ser" fica claro ao longo da obra por meio da caracterização marioniana da onto-teo-logia heideggeriana (Cf. Ibidem, cap. 2, § 3). Por ser, Marion compreende, à luz de Heidegger, o horizonte condicionador da aparição do ente. Enquanto princípio ontológico de condicionamento do ente, o ser é posicionador do modo de ser do que quer que seja. Deste modo, como vimos, Deus aparece como condicionado pelo horizonte do ser e condicionador (como ser último) dos demais entes. "Deus sem o ser" é a expressão para a disjunção entre Deus e onto-teo-logia. Assim como Lévinas, Marion preocupa-se em ressignificar Deus de outro modo que ser. Porém, diferente do pensador lituano, Marion não pretende desontologizar Deus por meio somente de uma virada ética da fenomenologia. Ora, a fenomenologia marioniana ressignificará Deus através de uma dupla estratégia, a saber, contrapondo os conceitos de ídolo e ícone e reinterpretando a iconicidade do divino desontologizado através do conceito (fenomenológico) de fenômeno saturado. Se devemos, no presente momento, caracterizar a ressignificação marioniana de Deus, é preciso inicialmente assinalar os caracteres fundamentais dos conceitos de ídolo e ícone e, em seguida, mostrar como Marion identifica a divindade que se dá iconicamente com um tipo específico de fenômeno saturado.

Os conceitos fenomenológicos de ídolo e ícone aparecem contrastivamente ${ }^{9}$ nas duas obras onde são mais descritos, a saber, Deus sem o ser e O ídolo e a distância. Com eles, Marion consegue descrever dois modos de a divindade se dar à visada intencional humana, por meio de uma abordagem que se inicia no que claramente poder-se-ia chamar de horizonte "estético", uma vez que tais

9É neste sentido que Marion afirma: “Que l'idole ne puísse s'aborder que dans l'antagonisme qui l'unit immanquablement à l'icône, il n'en faut sans doute pas discutir' (2013, p. 15). 
operadores conceituais são primeiramente explicitados por meio da análise do que significa ídolo e ícone nas obras de arte. Consequentemente, ídolo e ícone são dois conceitos fenomenológicos que descerram um novo modo de compreensão da divindade e de nosso acesso a ela. Contudo, ídolo e ícone aparecem, em um primeiro momento, como conceitos que descrevem duas tendências ou hegemonias históricas de a divindade se dar em meio ao âmbito artístico. Como assinala Marion, estes "conceitos pertencem, com efeito, a dois momentos históricos distintos e, em certo sentido, contrapostos" (DSE, p. 15). O caráter histórico do ídolo e do ícone assinala que estes conceitos referem-se a modos históricos de aparição do ser do ente, ou seja, são conceitos de base ontológica, ainda que o conceito de ícone descreva um modo de aparição da divindade irredutível à horizontalidade do seer. Neste sentido, o caráter idólatra do desvelamento do ente aparece paradigmaticamente no "esplendor grego do visível" e o modo icônico de desvelamento do ente se dá sobretudo de modo "renovado do hebreu no Novo Testamento" (Idem). Deve-se levar em conta que comumente entende-se por ídolo e ícone imagens artísticas que têm como finalidade "representar" algo divino ou mesmo uma divindade. Contudo, a iconoclastia judaico-cristã por vezes assinalou, de modo crítico, a impossibilidade deste objetivo, o que levou a denúncia de idolatria justamente porque considerou que a redução de uma divindade aos limites de uma "imagem" nada mais é que uma divindade falsa, sem vida: um ídolo. Ídolo, neste sentido, tornou-se sinônimo de simulacro. Ora, Marion não compreende deste modo o conceito de ídolo. Este de algum modo mostra a presença efetiva da divindade, pois desvela seu ser de fato. Ainda que não saibamos o que se entende por ídolo e ícone é preciso, antes de tudo, deixar claro que ídolo e ícone são conceitos que dizem respeito ao modo como fenomenologicamente o ser do ente deixa aparecer a divindade. São conceitos portanto relacionais, isto é, relacionados com o modo de aparição da divindade. Como isso se dá, é o que devemos agora saber.

Ídolos e ícones são entes que deixam aparecer a divindade. Por isso, a divindade não se dá "nua e crua", mas por meio de... Isto já assinala que um ente que transforma-se em ídolo ou ícone possui um caráter de remissão, pois ele deve deixar ser ou trazer à vigência a divindade. Marion chama este caráter de signa. Somente por meio da ideia de signa se pode compreender como e por que um ente artístico (e, como veremos, um conceito) pode deixar irromper o comportamento da veneração. O que se entende pelo caráter de signa diz respeito, antes de tudo, ao fato de cada obra de arte que refere-se ao divino deixa vir a lume a alteridade divina em meio à constituição da obra. Em outras palavras: é óbvio que uma divindade não se reduz a uma obra de arte; contudo, o caráter 
de signum deixa aparecer justamente a "transcendência" divina (expressão que Marion não utiliza, mas que nós lançamos mão para explicitar melhor o que está em jogo com a ideia de signum) não em uma instância suprassensível, mas justamente por meio da aparição da obra de arte. Por isso mesmo, a obra não é, neste caso, um símbolo, pois ela não se refere a algo estrangeiro, a algum ente oculto, divorciado da obra de arte que o traz à vigência. ${ }^{10} \mathrm{O}$ que caracteriza um signum é o fato dele conjugar visibilidade e invisibilidade, isto é, deixar a invisibilidade da divindade vigorar em plena unidade com a visibilidade da obra. Trata-se então de dois modos de tornar visível o invisível. Por isso, ídolo e ícone dizem respeito à visada, ou melhor, a dois modos distintos do divino, enquanto fenômeno invisível, tornar-se visível na presença da obra à visada humana. Como Marion afirma: "a maneira de ver decide o que se pode ver ou, em todo caso, ao menos negativamente, decide o que não poderá perceber-se do divino.”(Ibidem, p. 17) Dito isto, surge a questão: como ídolo e ícone desvelam o divino?

O primeiro aspecto da caracterização marioniana do ídolo, como já mencionado, aparece na desarticulação de sua essência com a noção de ilusão. Tratase de uma desconstrução do senso-comum que, pelos motivos mais diversos, identifica ídolo com semblância. Justamente isto é colocado em xeque por Marion, pelo simples fato de que o ídolo é visto. Aliás, ídolo é o que se vê. Como ele afirma: "O ídolo não merece ser denunciado como ilusório, posto que, por definição, se vê - eidolon, o que se vê (eidô, vídeo). Inclusive, não consiste mais que nisso: em que se pode ver, em que só se pode ver. Consiste então em vê-lo tão visivelmente que o fato mesmo de vê-lo basta para conhecê-lo - eidolon, o que se conhece pelo fato mesmo de que se viu (oïda).” (Ibidem, p. 18) Se o característico do ídolo não está no fato de ele iludir, isto não quer dizer que Marion se satisfaça com uma simples abordagem negativa: dizer o que o ídolo não é e, assim, fixar sua análise na simples denúncia de insuficiência do senso-comum. Para ele, o ídolo gera satisfação de uma visada específica. Como se deve compreender tal visada, é o que é necessário entender. Se o ídolo determina-se por uma visada (intencional), é porque a divindade que nele aparece preenche ou satisfaz a consciência (de onde irrompe a visada). É devido a esta consciência

10 Vale a pena reproduzir a passagem em que Marion caracteriza o signum e o diferencia de símbolo: "Signa: o termo latino é aqui muito significativo: só podem aspirar ao estatuto de contraditório de ídolo e/ou ícone aquelas obras que a arte trabalhou de tal maneira que não restringem sua visibilidade a elas mesmas (como é o caso do que se denomina muito corretamente as "artes de adorno"), mas que, como tais e permanecendo desta maneira absolutamente imanentes a elas mesmas, sinalizam indissoluvelmente para outro termo, ainda indeterminado. Precisemos: esse reenvio não sinaliza para uma instância diferente da que a própria obra de arte constitui em si mesma, sobredeterminando-a a partir do exterior mediante certo "valor simbólico'; ao contrário, esse reenvio constitui a dignidade mais essencial da obra; a obra só aparece como tal sinalizando, posto que só sinalizando vale como signum " (Ibidem, p. 16-17) 
que o idólatra pode criar uma obra que consigne aquilo que a ele desvelou-se. O que move a consciência idólatra nada mais é que a intenção de apreender o divino e satisfazer-se com tal apreensão. Isto significa que a busca empreendida pela consciência de visar e apreender o divino é paralisada e sua mobilidade consumada na apreensão objetivada. O ídolo é justamente o que aparece como satisfação da consciência. Um dos entes, aquele que servirá de obra idolátrica onde o divino se dá ao olhar, se destaca e passa a deslumbrar a visada da consciência. O deslumbramento se dá concomitantemente ao obscurecimento dos demais entes. O que a visada idólatra primeiramente vê é justamente o ídolo: o divino dado à visada por meio de um ente específico. Por isso, Marion chama o ídolo de "primeiro visível." (Idem) A visada do idólatra nada vê senão o que a satisfaz plenamente. Ora, se o ídolo não é fonte de ilusão, como a consciência não o experimenta como ídolo? Marion responde: por que o ídolo não é somente o primeiro visível, ele é também o espelho invisível.

O caráter de espelho invisível aparece como desdobramento do modo de realização da consciência idólatra. Esta busca preencher-se e locupletar-se na visada do divino. O divino que se dá a esta consciência mostra, de certo modo, como um espelho, o percurso trilhado pela consciência até chegar ao divino, ou seja, o divino deixa a consciência "saber" quantos entes ela transpassou até que se tornasse satisfeita. Isto porque, diz Marion, o ídolo funciona como um espelho e não um retrato que mostra algo em si fora de sua dinâmica intencional ou como uma fotografia que retrata os caracteres objetivos do fenômeno que se lhe desvela. Entretanto, por causa do deslumbramento da consciência idólatra, a função de espelho desempenhada pelo ídolo é obscurecida. Por quê? Marion responde: "A função de espelho se obscurece em virtude mesmo da função de espetáculo.” (Ibidem, p. 21) O fascínio proporcionado pelo ídolo impede a consciência de experimentar os limites do divino por ela apreendido, limites estes que convergem para a ideia de que, no ídolo, a "transcendência" do divino se reduz à amplitude do campo de visibilidade da consciência intencional. Neste sentido, no ídolo, de certo modo, a consciência humana condiciona o divino. Em outras palavras: no ídolo, a divindade fica disponível para o ser humano, uma vez que é a amplitude da visibilidade de sua consciência intencional que condiciona o modo de aparição e veneração do divino. Isto não acontece somente pictoricamente; acontece também conceitualmente. Todo conceito que se refere à divindade, que nasce da consignação daquilo que apreendeu o espírito, pode ter a pretensão de reduzir sua alteridade e distância (Cf. Idem) à amplitude do poder de captação do próprio conceito, funcionando assim como ídolo conceptual. (Cf. Ibidem, p. 26-27) 
Se com o ídolo a divindade reduz-se à amplitude do olhar, com o ícone é diferente. No artigo “Da 'morte de Deus' aos nomes divinos: itinerário teológico da metafísica", Marion afirma que o ícone não nasce de uma nova visada, mas de um "ser visado". Nas suas palavras: "Converter a visada não significa nem ver outros espetáculos, nem ver de uma maneira radicalmente nova, mas parar de ver os objetos ou visar objetivos, para receber uma outra visada que me vê, ver que um outro me vê, considerar que outro me considera." (MDND, p. 32) O outro que me vê no ícone é a divindade. Esta passa a se dar em sua distância, isto é, em sua irredutibilidade aos limites intrínsecos da visada intencional. Ora, para que isto se dê deste modo, o ícone deve alargar os limites da intencionalidade, mostrando à consciência o caráter excessivo da divindade. Em outras palavras: o ícone provoca a visada da consciência a ver de outro modo. O ícone provoca a visada intencional a apreender a irredutibilidade do divino em meio à sua visibilidade. ${ }^{11}$ Neste sentido, o ícone provoca a visada intencional a sempre dilatar-se, a sempre ir para além de si, a nunca satisfazer-se e paralisar-se em algum ente, a nunca chegar a um primeiro visível. Se não é a consciência intencional que impõe sua visada, é porque o divino aparece visando-nos. Nós é que somos o ponto onde incide a "intencionalidade" da divindade. A visada intencional da divindade funciona como uma convocação do nosso olhar. Somos chamados a ir sempre para além do que fomos, experimentando assim a profundidade do divino, que é inexaurível. Consequentemente, "o ícone se abre em um rosto que olha nossas visadas para convocá-las à sua profundidade" (DSE, p. 29)

Sem ser espelho invisível, o ícone é, como deixa entrever o termo hypostasis utilizado pela patrística para descrevê-lo e traduzido para o latim por persona, a visada do rosto invisível que nos encara em sua infinitude. (Cf. Ibidem, p. 3840) Como diz Marion: "O ícone nos encara - ele nos concerne, ao deixar advir visivelmente a intenção do invisível.” (Ibidem, p. 31) Por isso, se é o infinito a fonte da visada, é possível afirmar que o ícone é o espelho do invisível. Destarte, o ícone não nos permite apreender o divino - somente o ídolo nos permite tal apreensão. O ícone deixa irromper o invisível por meio do visível, sem que o invisível seja capturado. Portanto, nosso olhar não abarca a infinitude que se dá neste acontecimento revelador, razão pela qual Marion afirma que somente o ídolo se relaciona com a aisthesis, enquanto o ícone se relaciona com o apokalipsis (revelação) (Cf. Ibidem, p. 32-35) Se tais características aparecem na visibilidade de um ícone artístico, também se dão nos ícones conceptuais. Marion caracteriza estes como aqueles conceitos que renunciam compreender o incom-

11 Cf. DSE, p. 29: "O ícone, ao contrário, tenta fazer visível o invisível como tal." 
preensível e o concebem em sua própria desmesura (Cf. Ibidem, p. 35-37). Dito de outro modo: o caráter icônico dos conceitos aparece quando o conceito diz o infinito sem reduzi-lo aos seus limites intrínsecos. Trata-se de um dizer que acena para a distância do invisível, justamente porque não pretende capturá-lo.

Os conceitos de ídolo e ícone nos permitem vislumbrar uma saída para a crise da metafísica, uma vez que eles pretendem referir-se ao "absoluto", sem operacionalizar as dicotomias metafísicas pré-modernas e modernas. De qualquer modo, deve-se dizer que Marion, quando caracteriza os ídolos conceituais, encontra nestes a raiz da metafísica, uma vez que esta nada mais faz do que capturar a distância do invisível na imanência do conceito. Daí advém sua ideia deteriorada da distância do absoluto: esta distância deixa de ser uma retração infinita para ser pensada à luz da dicotomia sensível/suprassensível (Cf. ID, § 17-19). Com isso, Marion conquistou um novo horizonte de investigação da irredutibilidade divina em relação a quaisquer horizontes de condicionamento de sua aparição. Contudo, a ideia de ícone, central para ressignificar não metafisicamente Deus, deve ser aprofundado por meio da ideia marioniana de fenômeno saturado, uma vez que este tipo de fenômeno repensa a fenomenalidade por meio da suspensão da originariedade das noções fenomenológicas de eu constituinte (consciência ou Dasein) e horizonte constituidor (campo intencional, ser, época do seer). Neste caso, o parágrafo vinte e três (§ 23) de Ente dado e os capítulos "O fenômeno saturado" e "A banalidade do fenômeno", de O visível e revelado, fornecem justamente os contornos essenciais para a compreensão das bases fenomenológicas do ídolo e do ícone, que devem ser aqui sucintamente expostos Segundo Marion, a virtude da fenomenologia é ela mesma sinal de sua limitação. A fenomenologia liberta todo fenômeno da necessidade de ter de dar a razão de si por meio da suposição da existência de algum elemento que se situe para além de sua manifestação. Isto porque todo fenômeno, pelo simples fato de doar a si mesmo, tem o seu ser garantido em seu movimento de auto-mostração ou autod(o)ação (Gegebenheit). O fenômeno dá a si mesmo, não segundo a aparência, mas essencialmente. O que se dá presentifica efetivamente o que se dá. Como o fenômeno se dá para a consciência, esta testifica justamente a auto-dação do fenômeno. O que a consciência intui do que se dá traz à luz o ser do fenômeno. Destarte, nenhum fenômeno está em dívida com nada para além de si mesmo. Se o lema da fenomenologia é justamente voltar às coisas mesmas, então reconduzir a consciência à intuição dos fenômenos é consumar seu propósito: "Voltar às coisas mesmas equivale a reconhecer os fenômenos em si mesmos, sem submetê-los à condição (suficiente) de uma instância anterior (coisa em si, causa, princípio etc.).” (VR, p. 12) Neste sentido, 
o conceito que mais importa na compreensão da revolução husserliana é o de intuição. É por meio da intuição que a consciência apreende a automanifestação do fenômeno, já que o que ela apreende é a coisa ela mesma, que se dá sem porquê e sem para quê. Ora, se o que a fenomenologia entende por fenômeno não necessita de nenhuma razão suficiente para legitimar-se, então parece que a fenomenologia libera o campo para reabilitação dos fenômenos religiosos, uma vez que nossa consciência apreende intuitivamente diversos fenômenos religiosos que nos são dados de fato: louvor, adoração, fé etc. Se a metafísica deslegitima a revelação pelo fato de esta querer elevar-se a um ente invisível trans-racional, com a fenomenologia, esta crítica cai por terra, uma vez que toda intuição, por mais subjetiva ou abstrata que seja, garante uma doação efetiva.

Se a fenomenologia possibilita deslocar o eixo hermenêutico de compreensão do fenômeno religioso para um eixo não metafísico, não quer dizer que o modo como ela é caracterizada por Husserl e Heidegger não possua problema, quando o que está em jogo é o fenômeno da revelação divina. Marion, neste sentido, parte de um pressuposto para ele inquestionável, a saber, a incondicionalidade da revelação divina. Isto porque revelação significa auto-manifestação divina, isto é, Deus se entrega espontaneamente, por si mesmo, segundo a medida que lhe convém. Por isso, não há como antecipar esta auto-doação divina (Cf. Ibidem, p. 25 ss). Ora, justamente isto é um problema para a leitura marioniana da fenomenologia. Marion percebeu que toda fenomenologia trabalha com alguma noção de horizonte, noção esta que antecipa os fenômenos e condiciona seus modos de aparição. Por exemplo, em Husserl, todo fenômeno é condicionado pelo horizonte vivencial. Fora da vivência (Erlebnis), o eu não se assegura como lugar de constituição do fenômeno. Para Marion, a fenomenologia husserliana tem como objetivo primordial reduzir o real às coisas mesmas, isto é, "àquilo que eu provo efetivamente como dado em carne: todo fenômeno possível deve-se reconduzir a uma ou muitas vivências de consciência, portanto ao eu como a intersecção dessas vivências (pelo menos)" (Ibidem, p. 24). O eu aparece como índice de constituição do fenômeno vivenciado. Ora, o que se entende por revelação divina é inconstituível e não-vivenciável, pois, como diz Marion: "Aquilo que se revela, o eu não tem nenhuma ideia, nenhum esboço, nenhuma espera."(Ibidem, p. 25) O mesmo se dá com o conceito de seer em Heidegger: ele aparece como uma tela no interior da qual tudo, inclusive Deus, deve se enquadrar: "o ser desempenha, no caso de Deus, a função de uma tela; precede a iniciativa de se revelar, fixa o quadro da revelação, impõe ao dom revelado as condições de sua recepção" (VR, p. 28). 
Ao colocar em xeque e hegemonia do eu constituinte e do horizonte do ser, Marion parece cair em uma aporia: "Se a revelação exclui por princípio todo horizonte, não pode mais se apresentar em nenhum lugar, para nenhum olhar nem em nenhum fenômeno; perde assim toda relação com a fenomenalidade enquanto tal" (Ibidem, p. 33). Para coadunar a necessidade de absolutidade da revelação divina com a necessidade de horizontes de manifestação do divino, Marion diz que toda revelação aparece em algum horizonte, porém, a revelação divina "recusa toda condição a priori imposta à sua possibilidade." (Ibidem, p. 28) Marion, portanto, pretende salvaguardar a liberdade e espontaneidade de auto-manifestação de Deus. Contudo, Deus revela-se em algum horizonte histórico. Como então revelação e horizonte se relacionam? Marion responde: por meio da saturação do horizonte. A revelação divina não nega o horizonte do seer, tampouco nega os campos intencionais que constituem a ipseidade. Em outras palavras: a revelação divina se dá no horizonte do ser, assim como no outro, na carne, na relação consigo etc. Porém, a revelação excede tais campos e horizontes. Tal excesso perturba os limites de cada horizonte fenomenológico: "cada linha do fenômeno interfere em todas as outras, como se elas se cruzassem ou se refletissem, uma pela outra, ou cada uma nas margens da moldura." (Idem) Desta incomensurabilidade surge o paradoxo como modo de ser da relação entre revelação divina e horizonte fenomênico. O paradoxo assinala justamente o caráter excessivo da revelação divina, o que sinaliza o fato de a revelação caracterizar-se por ser um fenômeno saturado. Trata-se de perguntar pelo modo de ser do fenômeno saturado. Até que ponto a revelação divina é um fenômeno saturado privilegiado? Antes: o que se entende por fenômeno saturado?

A compreensão marioniana de fenômeno saturado é devedora de um arcabouço conceptual claramente kantiano e husserliano. Dito sucintamente: fenômeno saturado outra coisa não é senão fenômeno saturado de intuição. Trata-se de uma afirmação que nasce de uma transformação do modo como usualmente a fenomenologia husserliana apropriou-se de Kant. Para Kant, o conhecimento de qualquer fenômeno depende da estrutura transcendental do sujeito cognoscente. Esta estrutura é composta de modo dúplice. Por um lado, um fenômeno é recebido pelas formas transcendentais da sensibilidade que são o espaço e o tempo (condições a priori de auto-dação do fenômeno). Por outro, um fenômeno se constitui propriamente em objeto de conhecimento por meio da ação do entendimento, que pensa o que a sensibilidade capta por meio da aplicação das (doze) categorias que estruturam o próprio entendimento. Se o entendimento é ativo, a sensibilidade é passiva, uma vez ser ela receptora do fenômeno que se dá ao aparelho gnosiológico do ser humano. A apreensão do fenômeno 
empreendida pela sensibilidade, por não necessitar de mediação conceptual, é imediata, razão pela qual Kant diz que a sensibilidade intui o fenômeno, fornecendo ao entendimento a possibilidade de sua atuação. Todo conhecimento possível depende da articulação entre as condições transcendentais e formais do sujeito cognoscente. Nas palavras de Marion: "É possível todo fenômeno que concorda com a finitude do poder de conhecer e de suas exigências." (Ibidem, p. 39) Se a intuição possui aqui papel central, uma vez que é por meio dela que o fenômeno é doado ao sujeito, o fenômeno mesmo é dependente do condicionamento de uma estrutura a priori que determina o que e como conhecer, concomitantemente, determina o modo de ser de todo fenômeno, impossibilitando tudo aquilo que contradiz a estrutura transcendental do sujeito cognoscente. Se o pensamento crítico kantiano submete todo fenômeno e toda possibilidade de conhecer à estrutura transcendental do sujeito cognoscente universalmente válida, com a fenomenologia isto cai por terra, pois, na fenomenologia, "a intuição intervém não apenas como uma fonte de fato dos fenômenos, que assegura sua efetividade bruta sem ainda fundá-la em razão, mas como uma fonte de direito, justificadora de si mesma." (Ibidem, p. 41) A intuição não está subjugada a uma instância a priori que deve dar ao fenômeno sua razão. Como já dito, fenomenologia começa justamente redimindo a intuição e o fenômeno, uma vez que este passa a possuir em seu movimento doador sua razão de ser. Contudo, segundo Marion, a doação do fenômeno, por mais que esteja liberta de certas condições transcendentais, ainda se inscreve em certos limites, limites estes que, como visto, identificam-se com a noção de horizonte e com a noção de eu constituinte. Tais fenômenos, que só podem ser compreendidos por meio de sua remissão ao eu constituinte e aos horizontes (intencionais), são considerados por Marion como fenômenos comuns. Ora, estes fenômenos regulam-se pelo ideal de correspondência plena entre intenção e intuição ou noema e noese. De modo geral, quando se dá plena correspondência entre intenção e intuição, o conhecimento do objeto consuma-se. Neste sentido, o ideal gnosiológico que orienta a evidência dos fenômenos comuns é o do conhecimento pleno dos fenômenos como objetos. Ora, com os fenômenos saturados ocorre uma radical transformação neste modo de conhecimento dos fenômenos comuns.

O fenômeno saturado não possui qualquer relação de igualdade entre intuição e intenção. Nele irrompe uma intuição que dá mais, ou melhor, excessivamente mais que a intenção pode prever ou que a intenção pode visar. Ora, tal irrupção fenomênica não é rara, mas banal. A banalidade do fenômeno saturado diz respeito ao fato de que qualquer fenômeno comum pode tornar-se, a qualquer momento, um fenômeno saturado. Basta que a relação entre intuição e in- 
tenção se diferencie da relação comum e a intuição doe mais que o poder de determinação da intenção ou significação (ou mesmo conceito). ${ }^{12}$ Por este motivo, devido ao excesso assinalado, o fenômeno saturado, em relação ao modo como Kant interpreta os fenômenos cognoscíveis, pode ser caracterizado, simultaneamente, como: imprevisível, absoluto, incondicionado, inobservável (consequentemente, inobjetivável) e incomensurável (Cf. Ibidem, p. 57). Isto porque todo fenômeno saturado excede todo horizonte intencional e conceptual, além de exceder todo poder de constituição do eu. Dentre os fenômenos saturados, Marion destaca o ídolo, o acontecimento, a carne, o ícone e a revelação divina (Cf. ED, §§ 23-24). Interessa-nos aqui tão-somente os fenômenos saturados do ícone e da revelação.

Para Marion, à luz do conceito de fenômeno saturado, o ícone se exerce sob o aspecto do não visável e do irredutível ao eu (Cf. Ibidem, § 23, p. 380). Assim como havia dito em Deus sem o ser, Marion assinala que o ícone não oferece nenhum espetáculo à visada intencional, tampouco tolera qualquer espectador, "mas exerce inversamente sua própria visada sobre aquele que o encara" (Idem). Neste sentido, o ícone acontece quando o outro me encara. Contudo, seu olhar não é por mim visto; ele se abate sobre mim, invisível e silenciosamente e eu, sendo visto, intuo o rosto que me encara. Se este rosto não é objetivo, ele se dá como fenômeno cuja intuição não se coaduna com a significação ou com a intencionalidade da consciência. Ora, devemos lembrar que o que está em jogo no ícone é justamente a aparição da invisibilidade do divino na visibilidade da obra de arte ou do conceito. Neste caso, Marion considera o ícone como um tipo de fenômeno saturado em que a manifestação do divino não se reduz ao poder de constituição do eu e que se dá livre de todo condicionamento de qualquer noção de horizonte, seja do ser ou dos campos intencionais descerrados pela e para a consciência.

Se o conceito de fenômeno saturado permite reinterpretar a noção fenomenológica de ícone, isto se deve ao fato de Marion ter ampliado a ideia fenomenológica de doação. Marion inscreve na fenomenologia a noção de revelação, ainda que entenda por revelação um conceito que abarca dois aspectos do fenômeno saturado: a) o caráter propriamente dito do fenômeno saturado, que, para ser, depende de uma autorrevelação do fenômeno, para além dos horizontes que condicionam o modo de determinação dos fenômenos comuns. Como diz Marion: a revelação, em sentido estritamente fenomenológico, identifica-se com "uma aparição de si e a partir de si, que não submete sua possibilidade a

12 Como diz Marion: "A banalidade do fenômeno saturado sugere, diferentemente, que a maior parte dos fenômenos, se não todos, pode dar lugar à saturação pelo excesso neles da intuição sobre o conceito ou sobre a significação" (Ibidem, p. 148). 
nenhuma determinação prévia" (VR, p. 73). Destarte, todos os fenômenos saturados são modos de realização do tipo de fenômeno chamado de revelação; b) a revelação enquanto autorrevelação de Deus, que funda a teologia revelada. Neste caso, a fenomenologia não diz o que é o Deus revelado, mas assinala a possibilidade de sua revelação. Assim, Deus é o ente dado por excelência e o máximo grau de manifestação de um fenômeno do tipo saturado, uma vez que em sua doação se mesclam os demais tipos de fenômeno saturado (AD, p. 97). $\mathrm{O}$ ícone, como signum que traz à vigência o invisível no visível preservando a invisibilidade da divindade, atualiza um tipo de revelação que ainda não é a autorrevelação propriamente dita de Deus, que funda, por exemplo, a teologia revelada. Isto pode ser compreendido pelo fato de o ícone necessitar consignar na obra ou no conceito o rosto invisível que nos encara e, assim, trazer à presença, por meio de um signum, a visada invisível e infinita da divindade. O ser-visto-peladivindade pressupõe a autorrevelação de Deus. Sem a possibilidade desta, não há ícone. Ora, isto não significa que a revelação divina nada tenha a ver com o ícone. Nada disso. A auto-manifestação de Deus nos leva a ser encarado por ele e a não reduzi-lo a qualquer visada intencional, como ocorre no ídolo.

\section{Considerações finais}

A crise das meta-narrativas metafísicas evidenciada pelo acontecimento histórico da morte de Deus exigiu do pensamento um novo posicionamento da questão de Deus, não mais marcado por regimes explicativos do mundo condicionados pela estrutura binária sensível/suprassensível. Contudo, com a compreensão heideggeriana da metafísica como onto-teo-logia, a crise dos modos tradicionais de posicionamento da problema de Deus acirrou-se, uma vez que não somente é inviável pensar Deus por meio dos binarismos ontológicos que separam e hierarquizam sensível e inteligível, como a redutibilidade de Deus ao modo de posicionar a pergunta pelo ser do ente tomando como medida os caracteres fundacionais do ente enquanto tal reduz Deus ao âmbito da causalidade (de si e da totalidade) e justamente isto condiciona a divindade, roubando dela sua absolutidade. A identificação de Deus com o conceito de causalidade (sobretudo, com a causa eficiente) condiciona a divindade à amplitude semântica da ideia de ser (ou fundamento). Ora, ainda que Heidegger tenha contribuído sobremaneira para o reposicionamento da pergunta por Deus, sua tentativa de ressignificação da divindade, por meio da ideia de diferença ontológica, mesmo 
libertando Deus de caracteres ônticos, submete a divindade à horizontalidade do acontecimento histórico do seer. Deus, portanto, continua condicionado, ainda que esse condicionamento não esteja atrelado a qualquer ideia de causalidade. Neste sentido, Lévinas e Marion, levando adiante a caracterização heideggeriana do conceito de onto-teo-logia e não repetindo a resolução ontológica fornecida por Heidegger à ressignificação não metafísica de Deus, de modos distintos, libertaram Deus de quaisquer horizontes condicionadores e posicionadores de sua manifestação. Por isso, tanto Lévinas quanto Marion possibilitam pensar Deus por meio da ideia do acontecimento de uma gratuita automanifestação divina, irredutível ao seer heideggeriano e inabarcável pelas categorias do entendimento humano. Isto, contudo, não anula a possibilidade de uma relação efetiva com a divindade. Esta relação, seja no âmbito ético (Lévinas), seja saturando os horizontes de condicionamento dos fenômenos (Marion), sempre assinala um excesso que nos permite dizer que Deus excede o ser. Deus sem onto-teo-logia é, em verdade, um Deus cuja inteligibilidade excede o ser (ou seer).

Recebido em: 14/11/2015 Aprovado em: 15/01/2016

CABRAL, Alexandre Marques. Niilismo e Hierofania: uma abordagem a partir do confronto entre Nietzsche, Heidegger e a tradição cristã. Rio de janeiro: MAUAD X/FAPERJ, 2 vol., 2014/2015.

CASANOVA, Marco Antônio. "Pensamento em transição: Heidegger e o problema do outro início" In: DOWELL, João A. Mac. Heidegger: a questão da verdade do ser e sua essência no conjunto de seu pensamento. Rio de Janeiro: Via Verita, 2014.

HEIDEGGER, Martin. Sein und Zeit. Tübingen: Max Niemeyer, 2006.

. Contribuições à filosofia (Sobre o acontecimento apropriador). Trad. Marco Antônio Casanova. Rio de Janeiro: Via Verita, 2015. . Caminhos de floresta. Lisboa: Calouste Gulbekian, 2002.
. "Identidade e diferença" In: Col. Os pensadores. São Paulo: Abril, 1973.

LÉVINAS, Emmanuel. Deus, a morte e o tempo. Lisboa: Edições 70, 2012.

. Entre nós: Ensaios sobre a alteridade. Petrópolis: Vozes, 1997.

. Transcendência e Inteligibilidade. Lisboa: Edições 70, 1991. . De Deus que vem à ideia. Petrópolis: Vozes, 2008 . . Autrement qu'être ou au-delà de l'essence. Paris: Martinus Nijhoff, 1978. . De Dieu qui vient à l'idee. Paris: Vrin, 1998 b. Ética e infinito. Lisboa: Edições 70, 1988. 
Los imprevistos de la historia. Salamanca:

Sigueme, 2006.

. Totalidade e infinito. Lisboa: Edições 70,

2000.

. La realidad y su sombra. Libertad y manda-

to, Transcendência y altura. España: Trotta, 2001.

Violência do rosto. São Paulo: Loyola, 2014.

Humanismo do outro humano. Petrópolis:

Vozes, 1993.

MARION, Jean-Luc. Dieu sans l'être. Paris: Fayard, 2013.

.Etant donné. Paris: PUF, 2013 b.

. L'idole et la distance. Paris: Grasset, 1977.

. 'De la 'mort de Dieu' aux noms divins:

l'itinéraire théologique de la metaphysique". In: Laval théologique et philosophique. N. 41 (1), 1985, pp. 25-41.

- Acerca de la donación: una perspectiva fenomenológica. Buenos Aires: Jorge Baudino Ediciones, 2005. O visivel e o revelado. São Paulo: Loyola, 2010.

NIETZSCHE, Friedrich. Sämtliche Werke. Kritische Studienausgabe. Edição organizada por Giorgio Colli e Mazzino Montinari. 15 Vols. Berlim: Walter de Gruyter, 1967-1978.

A gaia ciência. Trad. de Paulo César de Souza. São Paulo: Companhia das Letras, 2003.

"Obras incompletas". In: Vol. Nietzsche, Col. Os Pensadores. Sel. de Gerárd Lebrun. Trad. de Rubens Rodrigues Torres Filho. São Paulo: Nova Cultural,1997.

SOUZA, Ricardo Timm. Razões Plurais: Itinerários da Racionalidade Ética no século XX. Rio Grande do Sul: EDIPUCRS, 2004. matismo infinito e a crítica da filosofia ocidental. Rio Grande do Sul: EDIPUCRS, 1999.

SPINOZA, Baruch. Ética. São Paulo: Autêntica, 2007. 